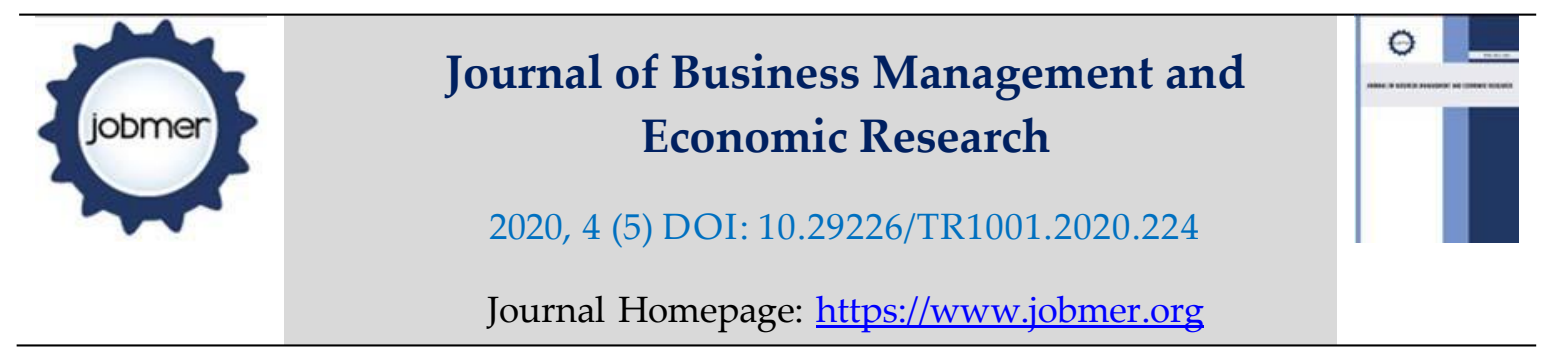

\title{
Effects of Employees Service Delivery Training on Customer Satisfaction: A Case of Amana Bank Main Branch Dar Es Salaam in Tanzania
}

\section{David Mosoma}

Lecturer, Department of Accounting and Finance

Ruaha Catholic University

\section{Salma Mazana}

MBA student,

St. Augustine University

\begin{abstract}
The purpose of this research was to study the effects of employees' service delivery training on customer satisfaction. The study intended to examine the influence of service delivery skills on customer satisfaction, the effect of service delivery competence on customer satisfaction, and lastly to determine the level of customers' satisfaction with Amana Bank service delivery. The study used mixed methods and revealed that training equips employees witheffective communication skills, patience skills, attentiveness skills, time management skills as well as closing ability, which are all vital for customer satisfaction. Also, employees expand their capacitiestooffer and managequality service, deliver promptly, offer satisfactory customer service, build good relationships with customers, as well as provide customers with support. Lastly, it was found that service delivery skills and competences positively influence customer satisfaction: customers consistently use services that they are satisfied with and ultimately persuade others to use the same services.
\end{abstract}

Keywords: Training, Service delivery, and Customer satisfaction

\section{Suggested Citation:}

Mosoma, D. \& Mazana, S. (2020). Effects of Employees Service Delivery Training on Customer Satisfaction: A Case Of Amana Bank Main Branch Dar Es Salaam in Tanzania. Journal of Business Management and Economic Research (JOBMER), Vol: 4, Issue: 5, 


\section{Introduction}

Satisfaction is a crucial concern for both customers and organizations including banks (Scriven, 2007). Banks around the world face intense slow balance sheet growth, uncertain economic outlook, and a growing threat from new entrants in the markets. Banks are also confronted with growing regulatory costs and increasing demands for greater fairness and clarity in their interactions with customers (Rossi, Freeman, and Wright, 2007). All of these factors encourage banks to adjust their focus on their customers by trainingtheir staffs on service delivery. Unfortunately, studies show that the number of dissatisfied customers outweighs the number of satisfied customers (Pasquariella, and Wishik, 2005). Service delivery training remains a key organizational initiative to enhance customer retention. It is an integral part of organizational business practices and overall corporate objectives (Ostroff and Ford, 2009). Service delivery training programs are generally devised, developed, and managed by human resource departments or the corporate training division of an organization with occasional expertise provided by external consultants and agencies. Several benefits accrue to an organization when employees are trained on customer service skills. The greatest benefit is that trained employees are able to demonstrate professional customer service skills that can improve customer satisfaction and customer loyalty (Torrington, 2006). This helps a bank to retain customers and improve profits as it costs less to retain a customer than to acquire a new one. In addition, contented customers are more likely to refer other potential customers through customer advocacy.

Employing professionalism in customer care can shorten the interaction time with customers. This allows an organization to serve more customers within the shortest time possible, possibly with fewer staff. Teaching all employees customer service skills allows them to have a common process and language for dealing with customers. This allows businesses to brand interactions and make excellent service part of their service package. Investing in employees through training makes employees feel valued and improves motivation (Smith, 2010). In addition, when employees treat customers well by using proper customer service skills, they are more likely to be treated well in return. Both these factors can help to increase customer satisfaction and enhance their retention.

Amana Bank Annual Report of 2018/2019 shows that many service delivery training sessions have been held for the Amana Bank staff but it appears that the effect of these training sessions on customer satisfaction has not been felt much. In Amana Bank, diverse trainings have been conducted to improve performance. Regardless of the trainingsconducted, Amana Banks' Financial Statements of the financial year 2018/2019 shows that on 31 ${ }^{\text {st }}$ December 2019, the Bank lost TZS 41.955 Million. However, from the year 2016 to 2017, there was a steady increase in Net Income of TZS 796.89 to TZS 989.65 million. This was equivalent to $24.19 \%$ increase in profitbut with a decrease of TZS 616.49 million, which isequivalent to $37.71 \%$ decrease in profit by December 2018. Due to dynamics and fluctuation in net income in Amana Bank for three consecutive years, training on service delivery was conducted to defend the market share and maximize profit. Despite these trainings, the bank is still not performing as expected. The critical question to be posed and answered is, why are service delivery trainings not yielding fruits? 


\section{Literature Review Theoretical Framework}

Reinforcement theory postulates that if learners receive feedback when they are learning and are rewarded when they demonstrate the 'correct' behaviour, then they are more likely to learn. These ideas are based on the theory of (Watson, 1913; Skinner, 1974). The theory states that individuals' behaviour is function of its consequences. This theory is sometimes called behaviourism. According to skinner, the external environment of the organization must be designed effectively and positively to motivate employees. Nevertheless, the theory is used extensively in training and development (Luthans, 2002). This theory is important to this study because it deals with employees behaviour and reward where by through understanding employees behaviour, the insrtuctor adopts the correct method of teaching. Also, the theory shows the importance of having a conducive work environment, whichencourages employees to feel comfortable during training sessions. Ultimately, feeback on the outcome of training is important to assess the effect of service delivery training on customer satisfaction specifically at Amana Bank.

\section{Empirical Literature Review}

Various studies were conducted on frontline employees. One of the studies was conducted by Proenca, Torres, and Sampaio (2017) in Portugal on Frontline employee empowerment and perceived customer satisfaction. The study adopted a survey design in which data were collected through online questionnaires. The results of the study indicated that training and development have a positive relation with customer satisfaction.

Also, another study was done by Pousa, Hardie, and Zhang (2018) on promoting frontline employee customer orientation in China.The study adopted survey research design in which data were collected through questionnaires and analyzed using structural equation modeling in AMOS as well as multi-group confirmatory factor analysis. The result of the study shows that managerial coaching is positively related to employee's performance. Also, the results suggested that managerial coaching might be a good strategy to promote relational behavior to frontline employees. Jeng (2018) conducted a study titled "Enhancing the creativity of frontline employees: the effects of job complexity and customer orientation in Taiwan and China." The study adopted survey research design in which data were collected from frontline employees through questionnaires and analyzed using structural question modeling. Results of the study indicate that job complexity increases customer orientation, which fosters employee creativity.

\section{Methodology}

This research study adopted descriptive research design, utilizing a mixed methods approach including qualitative and quantitative methods of research. Data were collected through questionnaires and were analyzed using SPSS 20: this facilitated interpretation of respondents' responses. A sample of 100 respondents was drawn using Yamene's formula from a population of 13, 106. Quantitative data were analyzed using descriptive statistics whereas qualitative data was used to conduct content analysis.

\section{Results}

\section{Overall Customer Satisfaction}

Overall customer satisfaction covers a broad spectrum and in its broad perspective can be analysed from different angles. Basing on the current study therefore, overall customer satisfaction was assessed based on readiness to continue using AMANA Bank services and willingness to recommend other people to use AMANA Bank on the basis that AMANA Bank servicespresentgood value. 
All these parameters scoredabove 75 percent indicating that customers are highly satisfied with AMANA Bank services as indicated in Figure 1.This result is also in line with results by Mary (2012) who found that the overall perception on bank service quality in AMANA Bank, Dar es Salaam branch was that the bank offers good quality services and most customers did not intend to shift to other banks. Moreover, Emmanuel (2010) on comparing between AMANA Bank services and other bank services found that all respondents rated AMANA bank services from average to very good. None of the respondents' rated the services as either excellent or poor.

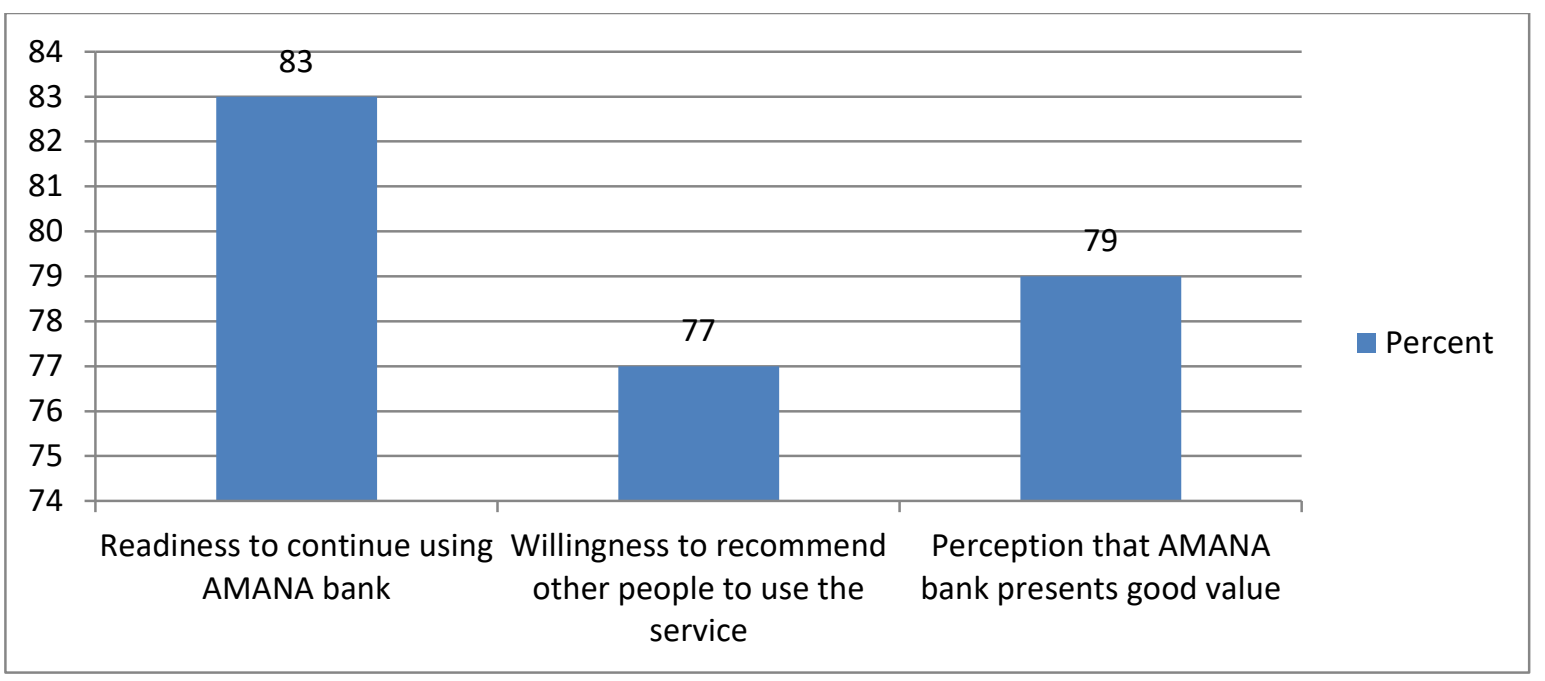

Figure 1. Overall customer satisfactions

Source: Field Data, (2019).

\section{Influence of Service Delivery Training on Customer Satisfaction}

Findings in Table 1revealed that the majority of respondents (74\%) admitted that service delivery training equips employees with effective communication skills forserving customers and provided them with patience skills. Furthermore, $71 \%$ of the respondents declared that service delivery training provides them with attentiveness skills. In the same vein, the majority of the customers (74\%) agreed that, service delivery training provides them with closing skills which are crucial when attending to customers. Lastly, $73 \%$ of all respondents declared that they were able to manage time after attending service delivery trainings.

These results are consistent with the study conducted by Bartel (1994) on productivity gains for the implementation of service delivery training program. The study found that to a large extent, training, and development increases efficiency of employees. Another study by Millas (2013) on the link between services quality training and customer satisfaction in retail banking in Tanzania found that service delivery training equips employees with effective communication skills and time management skills.

This is also cemented by one interviewee who said:

"We usually train our employees to improve their communication skills and provide them with attentiveness skills and time management skills, which help them to provide excellent customer services to our esteemed customers". 
Table 1. Influence of Service Delivery Training on Customer Satisfaction

\begin{tabular}{|c|c|c|c|c|c|}
\hline & Strongly Disagree & Disagree & Neutral & Agree & $\begin{array}{c}\text { Strongly } \\
\text { Agree }\end{array}$ \\
\hline Item & Percentage (Frq) & Per (Frq) & Per (Frq) & Per (Frq) & Per (Frq) \\
\hline $\begin{array}{l}\text { Equip employees } \\
\text { with effective } \\
\text { communication } \\
\text { skills in dealing } \\
\text { with customers }\end{array}$ & $5.0(5)$ & $3.0(3)$ & $18.0(18)$ & $40.0(40)$ & $34.0(34)$ \\
\hline $\begin{array}{l}\text { Service delivery } \\
\text { training provide } \\
\text { me with patience } \\
\text { skills for helping } \\
\text { customers }\end{array}$ & $2.0(2)$ & $5.0(5)$ & $20.0(20)$ & $40.0(40)$ & $34.0(34)$ \\
\hline $\begin{array}{l}\text { Service delivery } \\
\text { training provides } \\
\text { attentiveness skills } \\
\text { in helping } \\
\text { customers }\end{array}$ & $6.0(6)$ & $6.0(6)$ & $7.0(17)$ & $41.0(41)$ & $30.0(30)$ \\
\hline $\begin{array}{l}\text { Service delivery } \\
\text { training provides } \\
\text { closing skills for } \\
\text { helping customers }\end{array}$ & $4 . .0(4)$ & $4.0(4)$ & $18.0(18)$ & $42(42)$ & $32.0(32)$ \\
\hline $\begin{array}{l}\text { Service delivery } \\
\text { training equips me } \\
\text { with time } \\
\text { management skills }\end{array}$ & $2.0(2)$ & $5.0(5)$ & $20.0(20)$ & $47.0(47)$ & $26.0(26)$ \\
\hline
\end{tabular}

Source: Field Data, (2019).

The Effect of Service Delivery Employees' Competence on Customer Satisfaction

The respondents were asked to show the level of agreement or disagreement with the statements posed. Results in table 2 show that $74 \%$ of the respondents agreed that service delivery trainings enabled them to deliver, manage, and provide prompt andquality services. $72 \%$ agreed that service delivery training enabled them to support customers. On the same note, $74 \%$ admitted that service delivery training equips them with good customer service skills including how to deal with difficult customers.Lastly, $76 \%$ declared that service delivery training equips them with competence in building relations with customers.

On the same note, one of the top management staff admitted that:

"Our staffs always provide good customer services to customers by educating them on how to fill deposits and withdrawal forms. Theyare also able to deal with difficult customers by giving them special attention.Trainings equip our staff with various skills and knowledge on building good relations with their esteemed customers" 
The findings are also in line with Swart et al. (2005) who found that employee superior performance occur only because of good quality training programs that lead to employee motivation and satisfaction. Also, the results are in line with a study conducted by Etzel, Walker, \& Stanton (2007) who found that service delivery training enabled organizations to exceed the expectation of customers by communicating with the customer using a method that satisfies the customer.

Table 2. Effects of Service Delivery Competence on Customer Satisfaction

\begin{tabular}{lccccc}
\hline & Strongly Disagree & Disagree & Neutral & Agree & $\begin{array}{c}\text { Strongly } \\
\text { Agree }\end{array}$ \\
\hline \multicolumn{1}{c}{ Item } & Percentage (Frq) & Per (Frq) & Per (Frq) & Per (Frq) & Per (Frq) \\
$\begin{array}{l}\text { Service delivery } \\
\text { training has } \\
\text { enabled me to } \\
\text { manage quality } \\
\text { service }\end{array}$ & $4.0(4)$ & $7.0(7)$ & $15.0(15)$ & $46.0(46)$ & $28.0(28)$ \\
\hline $\begin{array}{l}\text { Service delivery } \\
\text { training has } \\
\text { enabled me to } \\
\text { provide customer } \\
\text { support }\end{array}$ & $0.0(0)$ & $13.0(13)$ & $15.0(15)$ & $33.0(33)$ & $39.0(39)$ \\
\hline $\begin{array}{l}\text { Service delivery } \\
\text { training has } \\
\text { enabled me to } \\
\text { deliver promptly }\end{array}$ & & & & & \\
\hline $\begin{array}{l}\text { Service delivery } \\
\text { training equips me } \\
\text { with good customer } \\
\text { serviceskills }\end{array}$ & $0 . .0(0)$ & & & & \\
\hline $\begin{array}{l}\text { Service delivery } \\
\text { training equips me } \\
\text { with competence in } \\
\text { building good } \\
\text { relations with } \\
\text { customers }\end{array}$ & & & & & \\
\hline
\end{tabular}

Source: Field Data, (2019).

\section{Reliability of Findings}

Results show the value of the coefficient alpha or Cronbach's alpha as the research scale is 0.884 or $88.4 \%$. This gets over the percent of $80 \%$, which is an extragood value for the internal consequence of the conceptual construction of the investigated scale. If the researcher continues with the release of units, in other words with standardized value of variables, then the coefficient alpha will slightly increase the value of $\alpha=0.907$. This means that whether the number of items is increased, the Cronbach's alpha will take thevalue of 0.907 , which is excellent. 
Table 4. Reliability Statistics

\begin{tabular}{|r|r|r|}
\hline Cronbach's Alpha & $\begin{array}{c}\text { Cronbach's Alpha Based on Standardized } \\
\text { Items }\end{array}$ & N of Items \\
\hline .884 & .907 & 17 \\
\hline
\end{tabular}

Source: Field Data, (2019).

\section{Validity of the Study}

The validity of the study was measured using the Kaiser-Meyer-Olkin (KMO) and Bartlett's Test of sphericity through the SPSS. From table 5, the researcher found a sample sufficiency index of KMO by Kaiser-Meyer-Olkin, which compares the sizes of the observed correlation coefficients with the sizes of the partial correlationcoefficients for the sum of analysis variables which is 0.639 or $63.9 \%$ : it is reliable because it is above 0.5 or $50 \%$, which is the cut-off.

Table 5. KMO and Bartlett's Test

\begin{tabular}{|l|l|r|}
\hline \multicolumn{2}{|l|}{ Kaiser-Meyer-Olkin Measure of Sampling Adequacy. } & .639 \\
\hline & Approx. Chi-Square & 26.886 \\
Bartlett's Test of Sphericity & df & 6 \\
& Sig. & .000 \\
\hline
\end{tabular}

Source: Field Data, (2019).

\section{Conclusion}

It is concluded that service delivery employees' training equips employees witheffective communication skills to serve customers, patience skills to help customers, attentiveness skills to attend to customers, time management skills to serve customers promptly, as well as closing ability. It is also concluded that service delivery skills positively affect customers' satisfaction. Also, trainingson service delivery impart employees with service competency namely, ability tomanage quality service, delivering services promptly, good customer service, building good relations with customers, as well as providing customers with support. The study reveals that service delivery competence positively affects customer satisfaction. It is also concluded that customer satisfaction is measuredbyreadiness of customers to continue using the service, willingness to recommend others to use the service, as well as perceiving organizational services as valuable. The study concluded that the level of customer satisfaction is high at AMANA Bank as service delivery is satisfactory.

\section{References}

Ahmad, Z.K. and Bakar, R.A. (2003), The association between training and organizational commitmentamong the white-collar workers in Malaysia. International Journal of Training and Development, Vol. 7No. 3, pp. 166-85.

Armstrong, M. (2000). Understanding Training. Human Resource Management Practice( $8^{\text {thed}}$ ). Kogan page limited, London. pp: 543

Bartel, A.P. (1994), "Productivity gains for the implementation of employee training programs". Industrial Relations, Vol. 33 No. 4, pp. 411-28. 
Blanchard, P., \& Thacker, W. J. (2004). Effective Training: Systems, Strategies, and Practices (2 ${ }^{\text {nd }}$ Ed). Pearson Prentice Hall.

Bratton, J., \& Gold, J. (2007). Human Resource Management: Theory and Practice (4th Ed). Palgrave Macmillan, N.Y, New York

Bratton, J., \& Gold, J. (2012). Human Resource Management: Theory and Practice (5 ${ }^{\text {th }}$ Ed). Palgrave Macmillan, N.Y, New York

Cheramie, R.A., Sturman, M.C. and Walsh, K. (2007), "Executive career management: switchingorganizations and the boundary less career". Journal of Vocational Behavior.

Creswell, W. J. (2014). Research Design: Qualitative, Quantitative and Mixed Methods Approach (4 ${ }^{\text {th }}$ Ed). SAGE Publications, Inc.

Gaur, S.S., Sharma, P., Herjanto, H., Kingshott, P.J. (2017) "Impact of frontline service employees' acculturation behaviors on customer satisfaction and commitment in intercultural service encounters", Journal of Service Theory and Practice.

Ginsberg, L. (1997). Training for the long haul. Computer Shopper. Vol: 17, p: 4

Harrison, R. (2000), Employees Development. Beekman Publishing Management, Silver Lakes, Pretoria.

Jeng, S.P. (2018). Enhancing the creativity of frontline employees: the effects of job complexity and customer orientation, International Journal of Logistics Management

Kim, S. (2006), Public service motivation and organizational citizenship behavior in Korea. International Journal of Manpower, Vol. 26 No. 8, pp. 722-40.

Kishnaswami, O. R. (2003). Methodology of Research in Social Science. Himalaya Publishing House, Mumbai.

Kothari, C. R. (2008). Research Methodologies: Methods \& Techniques.New Age International Ltd, New Delhi, India.

Kotler, P., Armstrong, G., Wong, V., \& Saunders, J. (2008). Principles of Marketing. Financial Times Prentice Hall.

Liu, C., Chou, S.F.,Gan, B., \&Tu, J.H. (2015), How "quality" determines customer satisfaction, The TQM Journal. Vol. 27 ISS 5 pp. $576-590$

Lucas, R.W (2005). Customer Service: Building Successful Skills for the Twenty-fist Century (3 ${ }^{\text {rd }}$ Ed). McGraw-Hill Irwin.

Luthans, F. (2002). The Need for and Meaning of Positive Organizational Behavior. Journal of Organizational Behavior.Vol. 6, pp.695-706.

Millas, A. (2013). The Link Between Services Quality and Customer Satisfaction in the Retail Banking in Tanzania, Case Study of CRDB Bank (Unpublished Masters Dissertation). Open University of Tanzania.

Ndulilo, W.L. (2014). Assessment of Customer Satisfaction on Complaints Handling in Banks: A Case Study Barclays Bank Tanzania (Unpublished Masters Dissertation). Open University of Tanzania.

Noe, R. A. (2002). Employee Training and Development, (2nd Ed). McGraw-Hill Companies, Irwin.

Pousa, C., Hardie, T., \& Zhang, X. (2018). Promoting frontline employee customer orientation in China: a replication and a comparison, International Journal of Bank Marketing.doi.org/10.1108/IJBM-04-2017-0078

Proenca, T., Torres, A., Sampaio, A. S. (2017) Frontline employee empowerment and perceived customer satisfaction, Management Research: Journal of the Iberoamerican Academy of Management, Vol. 15 No 2.

Ruane, J. (2005). Essentials of Research Methods: A guide to social science research. Blackwell Publishing. 
Saunders, M., Lews, P., \&Thornhill, A. (2012). Research Methods for Business Students (6 Ed).Pearson Education Ltd.

Senguo, A.R., Xixiang, S., \&Kilango, C. N. (2017). Marketing Communication Based on Customer Satisfaction and Loyalty: Zantel Tanzania, International Journal of Innovation, Management and Technology, Vol. 8, No. 4, pp. 284-288

Singh, A. S., \& Masuku, M. B. (2014). Sampling techniques \& determination of sample size in applied statistics research. International Journal of Economics, Commerce and Management, II(11), 1-22.

Sultana, A., Irum, S., Ahmed K., \&Mehmood, N. (2012). Impact of Training on Employee Performance: A study of Telecommuication sector in Pakistan. Interdisciplinary Journal of Contemporary research in Business, Vol, 4, No 6.

Swart, J., Mann, C., Brown, S. \& Price, A. (2005). Human Resource Development: Strategy and Tactics. Elsevier Butterworth-Heinemann Publications, Oxford.

Szwarc, P. (2005). Researching Customer Satisfaction and Loyalty: How to Find Out What People Really Think. Kogan Page

Vavra, G.T. (1997). Improving Your Measurement of Customer Satisfaction: A Guide to Creating, Analyzing and Reporting Customer Satisfaction Measurement Programs. ASQC Quality Press

Werner, S., Schuler, R. S., \& Jackson, S. E (2012) Human Resources Management (11 ${ }^{\text {th }}$ Ed). South-Western Cengage Learning.

Wright, P. and Geroy, D.G. (2001), "Changing the mindset: the training myth and the need for wordclass performance". International Journal of Human Resource Management, Vol. 12 No. 4, pp. 586-600. 